\title{
Quality Change of Pork Patty Containing Lotus (Ne/umbo nucifera) Leaf and Root Powder during Refrigerated Storage
}

\author{
Kyung-Sook Park', Hyun-Suk Park', Young-Joon Choi', Yoon-Hee Moon², Kyung-Soo Lee, Min-Ju \\ $\mathrm{Kim}^{4}$ and In-Chul Jung *
}

\author{
${ }^{1}$ Division of Hotel Culinary Arts, Daegu Technical University, Daegu 704-721, Korea \\ ${ }^{2}$ Deptartment of Food Science and Biotechnology, Kyungsung University, Busan 608-736, Korea \\ ${ }^{3}$ Division of Food, Beverage and Culinary Arts, Yeungnam College of Science and Technology, Daegu 705-703, Korea \\ ${ }^{4}$ Hanjin Company, Busan 614-080, Korea
}

Received October 10, 2011 /Revised December 19, 2011 /Accepted December 20 , 2011

\begin{abstract}
This study was carried out to investigate the effect of lotus root and leaf powder on the quality characteristics of pork patty stored at $3{ }^{\circ} \mathrm{C}$ for 9 days. The pork patties were of four types: nothing added(control, T0), $0.5 \%$ lotus root powder added (T1), $0.25 \%$ lotus root and $0.25 \%$ lotus leaf powder added (T2), and $0.5 \%$ lotus leaf powder added (T3). The a value tended to decrease with longer storage period $(p<0.05)$. The $\mathrm{L}^{*}$ and $\mathrm{a}^{*}$ value of T3 had the lowest value among the samples, the $\mathrm{b}^{*}$ value T2 and T3 were higher than those of T0 and T1 $(p<0.05)$. Water holding capacity decreased with longer storage period $(p<0.05)$, the water holding capacity, cooking loss, increase rate of thickness and decrease rate of diameter were not significantly different among the samples. Hardness and chewiness increased and springiness decreased with longer storage period $(p<0.05)$. The $\mathrm{pH}$ creased with longer storage period $(p<0.05)$, but the VBN content not changed during storage. The TBARS values increased with longer storage period $(p<0.05)$, and those of T0, T1, T2 and T3 were 4.57, 1.85, 0.43 and $0.41 \mathrm{mg}$ $\mathrm{MA} / \mathrm{kg}$, respectively, after 9 days of the storage. The result suggest that the addition of lotus root and leaf powder at the same time, or addition of lotus leaf powder can be applied to pork patty to its functionality.
\end{abstract}

Key words : Pork patty, lotus root, lotus leaf, functionality

\section{서 론}

식육제품은 저장기간 연장, 품질저하 방지, 기호도 향상 등 을 위하여 값이 저렴한 합성항산화제인 butylated hydroxytoluene (BHT), butylated hydroxyanisol (BHA), propyl gallate 등을 사용하고 있고[24,26], 합성보존료로서 sorbic $\operatorname{acid}[27]$, 그리고 발색제로서 질산염 및 아질산염 등을 사용하 고 있다[39]. 그러나 이들 합성식품첨가물들이 발암인자로 의 심되면서 소비자들은 식육산업에서 합성식품첨가물들의 사 용이 감소되도록 바라고 있다[28]. 따라서 식육산업을 위하여 천연의 식품첨가물을 사용하는 것은 사용하기 전에 다각적인 안전성 검사가 필요 없는 천연의 제품이기 때문에 유리한 점 이 많다. 예를 들면 oregano, sage [13], rosemary [34], black pepper [25], tea [4], chickpea [36], tomato [19] 등 많은 천연제 품이 있다. 그러나 이들은 합성식품첨가물보다 값이 비싸고 효과가 적다. 따라서 많은 연구자들은 상대적으로 값이 싼 토 마토 껍질[35], 포도 씨[5], 감귤 껍질 및 씨[3], 당근 부산물[12] 등 부존자원으로부터 천연의 식품첨가물을 얻는데 초점을 맞

*Corresponding author Tel : +82-53-560-3851, Fax : +82-53-560-3859

E-mail : inchul3854@naver.com
추고 있다.

연(Nelumbonucifera)은 한국, 중국, 일본을 비롯한 동아시아, 태국, 대만, 인도를 중심으로 한 동남아시아 등에 널리 분포하 는 수생식물로서[1] 우리나라의 경우 각지에서 대량으로 생산 되고 있기 때문에 천연의 식품첨가물로 사용하기에 원료 공급 이 안정적이며 값이 저렴하다. 연근은 단단하고 사각사각한 조직감으로 인하여 샐러드, 피클, 튀김, 당과 등으로 이용하고 있고[8], 연잎은 차, 연잎 밥, 백숙 등에 이용하고 있다. 연근 및 연잎은 한방에서 여러 질병의 치료제로 사용되기도 하는데 연근은 지혈, 혈압강하, 니코틴 해독, 진정작용, 당뇨, 위궤양 및 빈혈 치료, 항비만, 항산화 작용 등 $[14,30,38,40]$ 이 있으며, 연잎은 해열, 지혈, 고지혈증 억제, 항산화 작용, 항균 작용 등[14,23]이 있는 것으로 알려져 있다. 연의 생리활성과 기능성 에 대한 연구는 활발하게 이루어져 왔으나 식육제품에 직접 이용한 연구는 드물다. Huang 등[14]은 연잎 추출물을 돈육과 우육 분쇄제품에 첨가하였을 경우 지질의 산화가 억제되고 metmyoglobin의 형성이 지연되었다고 하였으며, Choi 등[9] 은 분쇄돈육에 연잎을 첨가하였을 경우 TBARS와 과산화물가 가 대조구보다 낮다고 하였다. 그러나 연잎과 연근을 식육제 품에 함께 사용한 경우는 찾아볼 수 없다. 따라서 연근과 연잎 을 식육제품에 첨가하여 저장 중 품질특성을 규명하여 기능성 
식품의 신소재로서의 활용 가능성을 모색하는 기초자료로 활 용하고자 본 연구를 수행하였다.

\section{재료 및 방법}

\section{공시재료 및 돈육 패티 제조}

본 실험에 사용한 연(Nelumbonucifera)근과 잎은 동결건조 하여 100 mesh 체를 통과시켜 얻어진 분말로서, 연근은 (주)인 그린(Korea)에서 구입하였고, 연잎은 (주)다연(Korea)에서 구 입하여 돈육 패티에 이용하였다. 돈육은 냉장한 후지부위를 시중의 대형마트에서 구입하여 이용하였다. 돈육 패티는 후지 부위의 과도한 지방과 결체조직을 제거한 후 만육기(IS-12S, Ilshin Machine Co., Korea)를 이용하여 $3 \mathrm{~mm}$ 로 분쇄하였으 며, 지방은 대두유((주)사조)를 이용하였다. 돈육 패티 제조를 위한 원부재료의 배합비율은 Table 1 과 같다. 즉 분쇄된 돈육 후지부위 $88.0 \%$ 에 대두유 $5 \%$ 를 1분간 혼합한 다음 물 $5 \%$ 와 식염 $2.0 \%$ 를 첨가한 후 다시 1 분간 혼합하여 제조한 돈육 패티 (T0), 여기에 연근분말 $0.5 \%$ 를 첨가하여 제조한 돈육 패티(T1), 연근분말 $0.25 \%$ 와 연잎분말 $0.25 \%$ 를 첨가하여 제조한 돈육 패티(T2), 그리고 연잎분말 $0.5 \%$ 를 첨가하여 제조한 돈육 패티 (T3) 등 4 종류의 돈육 패티를 제조하였다. 연근분말과 연잎분 말 각각의 특성을 파악하고자 $\mathrm{T} 1$ 은 연근분말만 첨가하였고, $\mathrm{T} 3$ 는 연잎분말만 첨가하였다. 제조한 돈육 패티는 직경 82 $\mathrm{mm}$, 두께 $12 \mathrm{~mm}$ 의 미생물 배양용 페트리 접시에서 무게 $100 \pm 1 \mathrm{~g}$ 의 형태로 성형하여 $3 \pm 1^{\circ} \mathrm{C}$ 의 냉장실에서 9 일 동안 저 장하면서 실험하였고, 패티의 겔 형성을 위하여 제조 후 24시 간 경과한 시점을 0 일로 하였다.

\section{표면색깔 측정}

표면색깔은 색차계(Chromameter CR-200b, Minolta Camera Co., Japan)를 이용하여 명도(lightness, L"값), 적색도(redness, $a^{*}$ 값) 및 황색도(yellowness, $b^{*}$ 값)를 측정하였다. 색깔 보정을 위해 사용된 calibration plate의 $\mathrm{L}^{*}, \mathrm{a}^{*}$ 및 $\mathrm{b}^{*}$ 값은 각각 97.5 ,
-6.3 및 7.1 이었다.

\section{보수력 및 가열감량 측정}

보수력은 데시케이터에서 습기를 제거한 여과지 위에 시료 $0.3 \mathrm{~g}$ 을 올려놓고, planimeter (X-plan, Ushikata 360d II, Japan)로 눌러 여과지 위에 나타난 수분의 면적을 구하고 육의 표면적을 수분의 면적으로 나눈 값으로 표시하였다[15]. 가열 감량은 가스오븐렌지(RFO-900, Rinnai Co., Korea)를 사용하 여 $180^{\circ} \mathrm{C}$ 에서 10 분간 예열시킨 다음 $200^{\circ} \mathrm{C}$ 에서 15 분 동안 중 심부의 온도가 $75^{\circ} \mathrm{C}$ 가 되게 가열하였을 때 가열 전후의 차이 를 각각 백분율로 나타내었다.

\section{두께 및 직경 변화}

돈육 패티의 두께 및 직경변화는 가열 전후의 두께 및 직경 을 측정하고 결과는 다음 식[7]으로 나타내었다.

$$
\begin{gathered}
\text { Thickness } \\
\text { change }(\%)
\end{gathered}=\frac{\text { Raw thickness-Cooked thickness }}{\text { Raw thickness }} \times 100
$$$$
\begin{gathered}
\text { Diameter } \\
\text { change }(\%)
\end{gathered}=\frac{\text { Raw diameter-Cooked diameter }}{\text { Raw diameter }} \times 100
$$

\section{경도, 탄성 및 저작성 측정}

기계적 조직감은 돈육 패티를 가로×세로×높이를 각각 40×15×5 mm로 자르고 rheometer (CR-200D, SUN Scientific Co., Japan)를 이용하여 측정하였다. 경도(hardness), 탄성 (springiness), 응집성(cohesiveness)은 round adapter 25번을 이용하여 table speed $120 \mathrm{~mm} / \mathrm{min}$, graph interval $30 \mathrm{~m} / \mathrm{sec}$, load cell(Max) $2 \mathrm{~kg}$ 의 조건으로 측정하였다. 그리고 저작성 (chewiness)은 (peak max $\div$ distance) $\times$ cohesiveness $\times$ springiness값으로 나타내었다.

\section{$\mathrm{pH}$ 측정}

돈육 패티의 $\mathrm{pH}$ 측정은 대기온도에서 $\mathrm{pH} 4.00$ 과 $7.00 \mathrm{buf-}$ fer로 보정한 유리전극이 부착된 $\mathrm{pH}$ meter (ATI Orion 370,

Table 1. Formulation of pork patty containing lotus leaf and root powder

\begin{tabular}{lcccc}
\hline \multirow{2}{*}{ Ingredients } & \multicolumn{3}{c}{ Pork patty $^{1)}$} \\
\cline { 2 - 5 } & $\mathrm{T} 0$ & $\mathrm{~T} 1$ & $\mathrm{~T} 2$ & $\mathrm{~T}$ \\
\hline Pork ham meat (\%) & 88.0 & 88.0 & 88.0 & 88.0 \\
Soybean oil (\%) & 5.0 & 5.0 & 5.0 & 5.0 \\
Ice water (\%) & 5.0 & 5.0 & 5.0 & 5.0 \\
Salt (\%) & 2.0 & 2.0 & 2.0 & 2.0 \\
Lotus root powder (\%) & - & 0.5 & 0.25 & - \\
Lotus leaf powder (\%) & - & - & 0.25 & 0.5 \\
\hline Total (\%) & 100.0 & 100.5 & 100.5 & 100.5 \\
\hline
\end{tabular}

${ }^{1}$ T0: control pork patty, $\mathrm{T} 1$ : pork patty containing lotus root powder $0.5 \%$, T2: pork patty containing lotus root powder $0.25 \%$ and leaf powder $0.25 \%$, T3: pork patty containing lotus leaf powder $0.5 \%$. 
USA)를 이용하여 측정하였는데, 시료는 분쇄한 후 $10 \mathrm{~g}$ 을 취 하여 증류수 $40 \mathrm{ml}$ 와 함께 균질한 후 측정하였다.

\section{$\mathrm{VBN}$ 함량 측정}

돈육 패티의 VBN (volatile basic nitrogen) 함량은 Conway unit를 이용한 미량확산법[21]에 의하여 측정하였다. 즉 시료 $2 \mathrm{~g}$ 을 증류수 $16 \mathrm{ml}$ 와 $20 \%$ perchloric acid $2 \mathrm{ml}$ 를 넣고 균질화 한 후 $3,000 \mathrm{rpm}$ 에서 15 분 동안 원심 분리하여 상층액을 취하 였다. 상층액 $1 \mathrm{ml}$ 와 $50 \% \mathrm{~K}_{2} \mathrm{CO}_{3} 1 \mathrm{ml}$ 를 Conway unit 외실에 넣고, 내실에는 $10 \%$ 붕산흡수제 $1 \mathrm{ml}$ 를 가한 후 $37^{\circ} \mathrm{C}$ 에서 80 분 동안 방치한 다음 $0.01 \mathrm{~N}-\mathrm{NaOH}$ 로 적정하였다. 그리고 공 시 대조구도 같은 방법으로 처리하여 아래와 같은 계산식에 의하여 VBN 함량을 구하였다.

$$
\begin{aligned}
& \text { VBN }(\mathrm{mg} \%)=0.14 \times \frac{(\mathrm{b}-\mathrm{a}) \times \mathrm{f}}{\mathrm{W}} \times 100 \times \mathrm{d} \\
& \mathrm{a}: \text { 공시험의 } 0.01 \mathrm{~N}-\mathrm{NaOH} \text { 적정량 }(\mathrm{ml}) \\
& \mathrm{b} \text { : 시료의 } 0.01 \mathrm{~N}-\mathrm{NaOH} \text { 적정량 }(\mathrm{ml}) \\
& \mathrm{W}: \text { 시료 채취량 }(\mathrm{g}) \\
& \mathrm{f}: 0.01 \mathrm{~N}-\mathrm{NaOH} \text { 의 역가 } \\
& \mathrm{d}: \text { 희석배수 }
\end{aligned}
$$

\section{TBARS 측정}

TBARS (2-thiobarbituric acid reactive substances)는 돈육 패 티 $2 \mathrm{~g}$ 을 3 배의 증류수로 균질한 다음 여과하여 얻어진 여액 1 $\mathrm{ml}$ 에 7.2\% BHT (dibutylhydroxy toluene) $50 \mathrm{\mu l}$ 를 첨가하고 산화
반응을 정지시켰다. 반응 혼합물 $2 \mathrm{ml}$ 에 TBA (2-thiobatbituric acid) 시약 $2 \mathrm{ml}$ 를 가하여 혼합한 후 끓는 물에서 15 분간 가열 하고 냉수에 식힌 다음 $2,000 \times g$ 로 원심분리 시켜 상층액을 $531 \mathrm{~nm}$ 에서 흡광도를 측정하였다. 공시료는 시료 대신 증류수 를 이용하여 같은 방법으로 측정하였다. TBARS는 흡광도 수 치에 5.88 을 곱하여 계산한 후 시료 $\mathrm{kg}$ 당 반응물 $\mathrm{mg}$ malonaldehyde로 계산하였다[6].

\section{통계처리}

통계처리를 위하여 모든 실험은 3 회 이상 반복 측정한 후 평균표표눈편차로 나타내었고, 통계처리는 SPSS 14.0 (statistical package for social science, SPSS Inc., Chicago II., USA)을 이 용 하였으며, 실험군들 사이의 유의성은 $p<0.05$ 수준에서 분산 분석(ANOVA)을 실시한 후 유의한 차이가 있는 경우 $p<0.05$ 수준에서 Ducan's multiple test로 시료들 사이의 유의성을 검 정하였다.

\section{결 과}

\section{냉장 중 돈육 패티의 색깔변화}

본 연구는 돈육 패티를 $3 \pm 1^{\circ} \mathrm{C}$ 에서 9일 동안 냉장하면서 색 깔의 변화를 관찰하고 그 결과를 Table 2에 나타내었다. 명도

\begin{tabular}{|c|c|c|c|c|c|}
\hline \multirow{2}{*}{ Color } & \multirow{2}{*}{ Pork patty ${ }^{1)}$} & \multicolumn{4}{|c|}{ Storage time (days) } \\
\hline & & 0 & 3 & 6 & 9 \\
\hline \multirow{4}{*}{$\mathrm{L}^{* 2)}$} & T0 & $48.48 \pm 1.12^{b}$ & $53.36 \pm 1.22^{\mathrm{aA}}$ & $50.62 \pm 1.82^{\mathrm{ab}}$ & $53.00 \pm 1.43^{\mathrm{a}}$ \\
\hline & $\mathrm{T} 1$ & $49.16 \pm 0.44^{b}$ & $53.50 \pm 2.09^{\mathrm{aA}}$ & $51.10 \pm 2.01^{\mathrm{ab}}$ & $52.32 \pm 1.54^{\mathrm{a}}$ \\
\hline & $\mathrm{T} 2$ & $48.76 \pm 1.00^{b}$ & $51.70 \pm 0.87^{\mathrm{AA}}$ & $50.22 \pm 1.01^{\mathrm{ab}}$ & $51.52 \pm 1.00^{\mathrm{a}}$ \\
\hline & $\mathrm{T} 3$ & $48.04 \pm 1.60$ & $48.60 \pm 1.65^{\mathrm{B}}$ & $48.18 \pm 1.11$ & $49.58 \pm 1.30$ \\
\hline \multirow{4}{*}{$a^{* 3)}$} & T0 & $7.54 \pm 0.55^{\mathrm{aA}}$ & $3.94 \pm 2.44^{\mathrm{bA}}$ & $4.28 \pm 1.14^{\mathrm{bA}}$ & $3.46 \pm 0.58^{\mathrm{bA}}$ \\
\hline & $\mathrm{T} 1$ & $6.76 \pm 0.58^{\mathrm{aA}}$ & $4.70 \pm 1.18^{\mathrm{bA}}$ & $4.88 \pm 0.60^{\mathrm{bA}}$ & $1.90 \pm 0.87^{\mathrm{cB}}$ \\
\hline & $\mathrm{T} 2$ & $1.42 \pm 0.64^{\mathrm{aB}}$ & $0.36 \pm 0.91^{\mathrm{bcB}}$ & $1.10 \pm 0.44^{\mathrm{abB}}$ & $-0.58 \pm 0.61^{\mathrm{cC}}$ \\
\hline & $\mathrm{T} 3$ & $1.18 \pm 0.45^{\mathrm{aB}}$ & $-1.92 \pm 0.75^{\mathrm{bB}}$ & $-2.58 \pm 0.73^{\mathrm{bcC}}$ & $-3.68 \pm 0.97^{\mathrm{cD}}$ \\
\hline \multirow{4}{*}{$\mathrm{b}^{* 4)}$} & T0 & $7.88 \pm 0.60^{B}$ & $9.00 \pm 0.96^{\mathrm{C}}$ & $8.26 \pm 0.41^{\mathrm{C}}$ & $9.36 \pm 1.29^{B}$ \\
\hline & $\mathrm{T} 1$ & $7.94 \pm 0.36^{\mathrm{B}}$ & $8.34 \pm 1.19^{C}$ & $8.28 \pm 0.72^{C}$ & $7.30 \pm 0.57^{\mathrm{C}}$ \\
\hline & $\mathrm{T} 2$ & $12.00 \pm 0.73^{\mathrm{A}}$ & $10.02 \pm 1.20^{\mathrm{B}}$ & $11.24 \pm 1.10^{\text {B }}$ & $10.56 \pm 4.40^{\mathrm{A}}$ \\
\hline & $\mathrm{T} 3$ & $12.94 \pm 1.44^{\mathrm{A}}$ & $12.76 \pm 1.00^{\mathrm{A}}$ & $13.24 \pm 1.18^{\mathrm{A}}$ & $12.44 \pm 1.22^{\mathrm{A}}$ \\
\hline
\end{tabular}
를 나타내는 $\mathrm{L}^{*}$ 값은 대조군(T0), 연근분말 첨가군(T1) 그리고 연근 및 연잎분말 첨가군(T2)은 냉장 0 일째 가장 낮았고 냉장 3 일 이후부터는 변화가 없었다( $p \times 0.05)$. 그러나 연잎분말 첨가 군(T3)은 저장 초기부터 저장 9 일까지 명도의 변화가 없었다.

Table 2. Changes in surface color of pork patty during storage at $3 \pm 1^{\circ} \mathrm{C}$

\footnotetext{
${ }^{1)}$ See the Table 1.

${ }^{2)}$ Lightness.

${ }^{3)}$ Redness.

4) Yellowness.

Values are mean \pm standard deviation.

${ }^{\mathrm{a}-\mathrm{c}}$ Means with different superscripts in the same row significantly differ at $p<0.05$.

${ }^{\mathrm{A}-\mathrm{C}}$ Means with different superscripts in the same column significantly differ at $p \ll 0.05$.
} 
적색도를 나타내는 $a^{*}$ 값은 저장기간이 경과하면서 낮아지는 경향이었으며, 연잎분말을 첨가한 $\mathrm{T} 3$ 의 a*값이 가장 낮게 형성 되었다 $(p<0.05)$. 황색도를 나타내는 $b^{*}$ 값은 저장 중 유의한 변 화가 없었으며, 저장 중 $\mathrm{T} 3$ 의 황색도가 높게 유지되는 경향이 었다.

\section{냉장 중 돈육 패티의 보수력, 가열감량, 두께 증가율 및 직} 경 감소율

돈육 패티 냉장 중 보수력, 가열감량, 두께 증가율 및 직경 감소율을 측정한 결과는 Table 3 과 같다. 보수력은 저장 3 일째 가 50.04 58.40\%로 가장 높았으며, 그 이후 저장기간이 경과하 면서 낮아지는 경향이었다 $(p<0.05)$. 가열감량과 두께 증가율 은 저장 중 변화가 없었으며, 직경 감소율은 $\mathrm{T} 0$ 가 저장 9 일째 증가하는 경향이었고 나머지 패티들은 저장 중 유의한 변화가 없었다 $(p<0.05)$.

\section{냉장 중 돈육 패티의 경도, 탄성 및 저작성}

돈육 패티의 경도, 탄성 및 저작성을 실험한 결과는 Table 4 와 같다. 냉장 중 돈육 패티의 경도는 저장기간이 경과하면서 증가하는 경향이었으며, 연근분말(T1)을 첨가한 돈육 패티는 유의한 변화가 아니었다 $(p<0.05)$. 그리고 저장기간이 경과하 면서 연잎분말을 첨가한 돈육 패티(T3)의 경도가 유의하게 낮 았다( $p<0.05)$. 탄성은 저장기간이 경과하면서 모든 돈육 패티 가 유의하게 낮아지는 경향이었으며, 저장 9일째는 T2 및 T3의 탄성이 가장 낮았다 $(p<0.05)$. 그리고 저작성은 저장기간의 경
과와 함께 유의하게 증가하였으며, 저장 6 일째에는 연잎분말 을 첨가한 돈육 패티(T3)의 저작성이 가장 낮게 나타났다 $(p<0.05)$.

\section{냉장 중 돈육 패티의 $\mathrm{pH}$}

돈육 패티 냉장 중 $\mathrm{pH}$ 의 변화를 관찰한 결과는 Table 5 와 같다. 제조직후의 $\mathrm{pH}$ 는 $\mathrm{T} 0, \mathrm{~T} 1, \mathrm{~T} 2$ 및 $\mathrm{T} 3$ 가 각각 5.44. 5.32, 5.27 및 5.29 였으나 냉장기간이 경과하면서 점점 유의하게 증 가하여 냉장 9 일째는 각각 $5.47,5.43,5.46$ 및 5.45 를 나타내었 다 $(p<0.05)$. 그리고 제조직후의 $\mathrm{pH}$ 는 $\mathrm{T} 0$ 가 가장 높았으나 저 장 9 일째에는 시료들 사이에 유의한 차이가 없었다 $(p<0.05)$.

\section{냉장 중 돈육 패티의 VBN 함량}

냉장 중 돈육 패티의 VBN 함량 변화는 Table 6에 나타내었 다. 모든 시료들의 $\mathrm{VBN}$ 함량은 $12.09 \sim 14.70 \mathrm{mg} \%$ 로서 냉장에 의한 변화가 없었으며, 시료들 사이에도 유의한 차이가 없어 서 연근 및 연잎분말의 첨가는 VBN 함량에는 영향을 미치지 않음을 알 수 있었다.

\section{냉장 중 돈육 패티의 TBARS}

돈육 패티를 냉장하면서 측정한 TBARS의 결과를 Table 7 에 나타내었다. 연근 및 연잎분말을 첨가하지 않은 대조군(T0) 은 제조직후의 TBARS가 $0.59 \mathrm{mg} \mathrm{MA} / \mathrm{kg}$ 이었으나 냉장 중 유의하게 증가하여 $4.57 \mathrm{mg} \mathrm{MA} / \mathrm{kg}$ 을 나타내었다( $p<0.05)$. 그 리고 연근분말을 첨가한 $\mathrm{T} 1$, 연근 및 연잎 혼합분말을 첨가한

Table 3. Changes in Water holding capacity (WHC), cooking loss (CL), increase rate of thickness (IRT) and decrease rate of diameter (DRD) of pork patty during storage at $3 \pm 1^{\circ} \mathrm{C}$

\begin{tabular}{|c|c|c|c|c|c|}
\hline \multirow{2}{*}{ Items } & \multirow{2}{*}{ Pork patty ${ }^{1)}$} & \multicolumn{4}{|c|}{ Storage time (days) } \\
\hline & & 0 & 3 & 6 & 9 \\
\hline \multirow{4}{*}{ WHC } & T0 & $54.09 \pm 0.42^{b}$ & $58.40 \pm 2.79^{a}$ & $47.07 \pm 1.08^{\mathrm{C}}$ & $43.28 \pm 1.07^{\mathrm{d}}$ \\
\hline & $\mathrm{T} 1$ & $48.78 \pm 7.62^{\mathrm{ab}}$ & $52.05 \pm 3.58^{\mathrm{a}}$ & $44.74 \pm 2.70^{b}$ & $45.56 \pm 0.61^{b}$ \\
\hline & $\mathrm{T} 2$ & $50.40 \pm 3.36^{\mathrm{a}}$ & $50.04 \pm 3.71^{\mathrm{a}}$ & $45.32 \pm 0.53^{b}$ & $45.91 \pm 3.62^{b}$ \\
\hline & $\mathrm{T} 3$ & $50.14 \pm 2.04^{\mathrm{a}}$ & $53.37 \pm 3.40^{\mathrm{a}}$ & $43.41 \pm 3.15^{b}$ & $45.33 \pm 2.09^{b}$ \\
\hline \multirow{4}{*}{$\mathrm{CL}$} & T0 & $18.45 \pm 2.75$ & $16.44 \pm 1.89$ & $14.67 \pm 2.57$ & $17.13 \pm 2.21$ \\
\hline & $\mathrm{T} 1$ & $15.47 \pm 1.93$ & $15.48 \pm 1.63$ & $15.42 \pm 1.79$ & $14.97 \pm 2.05$ \\
\hline & $\mathrm{T} 2$ & $15.64 \pm 2.01$ & $16.67 \pm 1.83$ & $15.44 \pm 2.09$ & $18.61 \pm 2.46$ \\
\hline & $\mathrm{T} 3$ & $15.10 \pm 2.12$ & $16.16 \pm 1.59$ & $14.90 \pm 1.77$ & $16.53 \pm 2.05$ \\
\hline \multirow{4}{*}{ IRT } & T0 & $5.26 \pm 0.95$ & $4.88 \pm 0.74$ & $4.76 \pm 0.85$ & $4.94 \pm 0.61$ \\
\hline & $\mathrm{T} 1$ & $5.13 \pm 0.73$ & $4.65 \pm 0.91$ & $4.89 \pm 0.83$ & $4.54 \pm 0.66$ \\
\hline & $\mathrm{T} 2$ & $5.00 \pm 0.69$ & $5.00 \pm 1.01$ & $4.65 \pm 0.78$ & $5.26 \pm 0.96$ \\
\hline & $\mathrm{T} 3$ & $5.00 \pm 0.77$ & $4.97 \pm 0.86$ & $5.26 \pm 0.71$ & $4.85 \pm 0.59$ \\
\hline \multirow{4}{*}{ DRD } & T0 & $7.89 \pm 1.05^{b}$ & $7.39 \pm 0.89^{b}$ & $8.10 \pm 1.11^{\mathrm{ab}}$ & $9.86 \pm 0.95^{\mathrm{a}}$ \\
\hline & $\mathrm{T} 1$ & $7.50 \pm 0.85$ & $7.25 \pm 1.21$ & $7.77 \pm 0.78$ & $8.97 \pm 1.32$ \\
\hline & $\mathrm{T} 2$ & $7.78 \pm 1.26$ & $7.99 \pm 0.82$ & $8.24 \pm 0.99$ & $9.24 \pm 0.93$ \\
\hline & $\mathrm{T} 3$ & $7.79 \pm 0.84$ & $8.42 \pm 1.26$ & $8.39 \pm 1.33$ & $8.59 \pm 0.99$ \\
\hline
\end{tabular}

${ }^{1)}$ See the Table 1.

Values are mean \pm standard deviation.

${ }^{\mathrm{a}-\mathrm{c}}$ Means with different superscripts in the same row significantly differ at $p \ll 0.05$. 
Table 4. Changes in hardness, springiness and chewiness of pork patty during storage at $3 \pm 1^{\circ} \mathrm{C}$

\begin{tabular}{|c|c|c|c|c|c|}
\hline \multirow{2}{*}{ Items } & \multirow{2}{*}{ Pork patty ${ }^{1)}$} & \multicolumn{4}{|c|}{ Storage time (days) } \\
\hline & & 0 & 3 & 6 & 9 \\
\hline \multirow{4}{*}{$\begin{array}{l}\text { Hardness } \\
\left(\mathrm{g} / \mathrm{cm}^{2}\right)\end{array}$} & T0 & $7.41 \pm 0.31^{\mathrm{ab}}$ & $7.32 \pm 0.24^{b}$ & $7.84 \pm 0.26^{\mathrm{aA}}$ & $7.89 \pm 0.16^{\mathrm{aA}}$ \\
\hline & $\mathrm{T} 1$ & $7.45 \pm 0.29$ & $7.63 \pm 0.27$ & $7.70 \pm 0.22^{\mathrm{AB}}$ & $7.75 \pm 0.19^{\mathrm{AB}}$ \\
\hline & $\mathrm{T} 2$ & $7.06 \pm 0.29^{b}$ & $7.10 \pm 0.21^{b}$ & $7.39 \pm 0.26^{\mathrm{abBC}}$ & $7.54 \pm 0.21^{\mathrm{aAB}}$ \\
\hline & $\mathrm{T} 3$ & $7.05 \pm 0.28^{b}$ & $7.04 \pm 0.28^{b}$ & $7.18 \pm 0.20^{\mathrm{abC}}$ & $7.46 \pm 0.19^{\mathrm{aB}}$ \\
\hline \multirow{4}{*}{$\begin{array}{c}\text { Springiness } \\
(\%)\end{array}$} & T0 & $87.67 \pm 4.34^{\mathrm{a}}$ & $83.53 \pm 3.67^{\mathrm{a}}$ & $71.67 \pm 2.63^{b}$ & $62.15 \pm 2.16^{\mathrm{cC}}$ \\
\hline & $\mathrm{T} 1$ & $89.99 \pm 2.66^{\mathrm{a}}$ & $85.77 \pm 5.77^{\mathrm{a}}$ & $76.24 \pm 3.00^{b}$ & $68.08 \pm 2.41^{\mathrm{cB}}$ \\
\hline & $\mathrm{T} 2$ & $87.78 \pm 2.48^{\mathrm{a}}$ & $82.07 \pm 6.90^{\mathrm{a}}$ & $78.42 \pm 1.95^{\mathrm{b}}$ & $75.86 \pm 4.70^{\mathrm{bA}}$ \\
\hline & $\mathrm{T} 3$ & $86.67 \pm 2.19^{\mathrm{a}}$ & $83.90 \pm 5.04^{\mathrm{a}}$ & $75.31 \pm 1.29^{b}$ & $76.38 \pm 3.98^{\mathrm{bA}}$ \\
\hline \multirow{4}{*}{$\begin{array}{c}\text { Chewiness } \\
\text { (g) }\end{array}$} & T0 & $60.12 \pm 4.01^{\mathrm{c}}$ & $64.29 \pm 4.32^{b}$ & $83.83 \pm 3.10^{\mathrm{aA}}$ & $85.90 \pm 3.94^{\mathrm{a}}$ \\
\hline & $\mathrm{T} 1$ & $61.11 \pm 1.75^{\mathrm{b}}$ & $61.27 \pm 5.82^{b}$ & $84.31 \pm 3.03^{\mathrm{aA}}$ & $89.98 \pm 2.09^{\mathrm{a}}$ \\
\hline & $\mathrm{T} 2$ & $58.17 \pm 4.45^{\mathrm{c}}$ & $60.65 \pm 3.90^{c}$ & $78.71 \pm 3.11^{\mathrm{bB}}$ & $88.78 \pm 3.77^{\mathrm{a}}$ \\
\hline & $\mathrm{T} 3$ & $60.09 \pm 5.21^{\mathrm{c}}$ & $60.82 \pm 2.95^{\mathrm{c}}$ & $70.04 \pm 3.62^{\mathrm{bC}}$ & $85.89 \pm 3.87^{\mathrm{a}}$ \\
\hline
\end{tabular}

${ }^{1)}$ See the Table 1.

Values are mean \pm standard deviation.

${ }^{\mathrm{a}-\mathrm{d}}$ Means with different superscripts in the same row significantly differ at $p<0.05$.

${ }^{A-C}$ Means with different superscripts in the same column significantly differ at $p<0.05$.

Table 5. Changes in $\mathrm{pH}$ of pork patty during storage at $3 \pm 1^{\circ} \mathrm{C}$

\begin{tabular}{ccccc}
\hline \multirow{2}{*}{ Pork patty $^{1)}$} & \multicolumn{4}{c}{ Storage time (days) } \\
\cline { 2 - 5 } & 0 & 3 & 6 & 9 \\
T0 & $5.44 \pm 0.01^{\mathrm{bA}}$ & $5.48 \pm 0.03^{\mathrm{abA}}$ & $5.49 \pm 0.02^{\mathrm{aA}}$ & $5.47 \pm 0.02^{\mathrm{ab}}$ \\
T1 & $5.32 \pm 0.07^{\mathrm{bB}}$ & $5.38 \pm 0.03^{\mathrm{abB}}$ & $5.43 \pm 0.03^{\mathrm{aB}}$ & $5.43 \pm 0.05^{\mathrm{a}}$ \\
T2 & $5.27 \pm 0.02^{\mathrm{cB}}$ & $5.33 \pm 0.01^{\mathrm{bBC}}$ & $5,34 \pm 0.01^{\mathrm{bC}}$ & $5.46 \pm 0.01^{\mathrm{a}}$ \\
T3 & $5.29 \pm 0.05^{\mathrm{CB}}$ & $5.27 \pm 0.04^{\mathrm{CC}}$ & $5.37 \pm 0.04^{\mathrm{bBC}}$ & $5.45 \pm 0.03^{\mathrm{a}}$ \\
\hline
\end{tabular}

${ }^{1)}$ See the Table 1.

Values are mean \pm standard deviation.

${ }^{\mathrm{a}-\mathrm{c}}$ Means with different superscripts in the same row significantly differ at $p<0.05$.

${ }^{A-C}$ Means with different superscripts in the same column significantly differ at $p<0.05$.

$\mathrm{T} 2$, 연잎분말을 첨가한 $\mathrm{T} 3$ 는 제조직후의 $\mathrm{TBARS}$ 가 각각 0.37 , 0.21 및 $0.10 \mathrm{mg} \mathrm{MA} / \mathrm{kg}$ 이었으나 냉장 9 일째 각각 $1.85,0.43$ 및 $0.41 \mathrm{mg} \mathrm{MA} / \mathrm{kg}$ 으로 유의하게 증가하여서 $(p<0.05)$ 연근이 나 연잎분말의 첨가가 돈육 패티의 TBARS에 유의하게 영향을 미쳤으며, 그 정도는 연잎분말이 연근분말보다 더 컸다.

\section{고 찰}

고기의 색깔은 myoglobin의 세 가지 유도체인 환원형의 진홍 색 deoxymyoglobin, 산소형의 선홍색 oxymyoglobin, 산화형의 암갈색 metmyoglobin의 비율에 영향을 받으며, 이들의 상대적인 비율이 $\mathrm{L}^{*}, \mathrm{a}^{*}$ 및 $\mathrm{b}^{*}$ 값에 영향을 미친다[22]. 특히 색깔은 소비자들 이 식육의 품질을 평가하는데 가장 중요한 항목으로 인식하고 있다. Hunter 색체계에서 $\mathrm{L}^{*}$ 값은 흑색의 0 에서 백색의 100 까지의 수치를 가지며, $a^{*}$ 값은 적색이 진하여 질수록 0 에서 +100 까지 증 가하고 녹색이 강하면 0 에서 -80 까지 감소한다. 그리고 $\mathrm{b}^{*}$ 값은 황 색이 강하면 +70 까지 증가하며, 청색이 강하면 -70 까지 감소한다 [31]. 따라서 저장 중 $\mathrm{T} 2$ 및 $\mathrm{T} 3$ 의 적색도가 다른 시료들에 비하여
특히 낮은 것은 연잎분말 녹색의 색소 특성이 반영되어 나타난 결과이며, 황색도가 높은 것은 일부의 녹색 분말이 산화되어 갈색 으로 변화됨으로서 나타난 현상으로 판단된다. 이러한 결과는 연 잎 및 보리 잎 분말[9], 깻잎 분말[17]을 첨가한 육제품의 적색도가 첨가하지 않은 대조구보다 낮았다는 결과와 일치하는 경향이었 다. 그리고 적색도의 감소는 산화에 의한 암갈색의 metmyoglobin의 형성에 기인하지만[33] 본 연구에서의 결과는 연근 및 연잎 에 함유된 항산화 물질에 의한 색깔의 변화억제보다는 연잎에 함유된 녹색성분이 더 크게 영향을 미친 것으로 생각된다. 본 실 험의 기계적 색깔 실험에서 연근분말은 돈육 패티의 색깔에 영향 을 미치지 않아 직접적인 사용이 가능하다. 그러나 연잎분말의 첨가는 적색도를 낮게 하지만 최근 색깔 있는 식물분말 즉, 쑥 분말, 깻잎 분말, 녹차 분말 등을 이용한 떡이나 빵과 같은 제품들 이 출시되면서 녹색을 띄는 제품들에 대하여 소비자들은 건강에 유익한 것으로 판단하는 경향이 있기 때문에 녹색을 나타내는 돈육 패티의 제조도 고려해 볼 사안으로 판단된다.

육제품의 보수력은 근원섬유 사이의 공간에 수분을 저장하 는 능력을 나타내는 것인데[16], 저장 3일째 보수력이 높아진 
Table 6. Changes in volatile basic nitrogen $(\mathrm{VBN})$ content of pork patty during storage at $3 \pm 1^{\circ} \mathrm{C}$

$(\mathrm{mg} \%)$

\begin{tabular}{ccccc}
\hline \multirow{2}{*}{ Pork patty $^{1)}$} & \multicolumn{4}{c}{ Storage time (days) } \\
\cline { 2 - 5 } & 0 & 3 & 6 & 9 \\
T0 & $13.49 \pm 1.86$ & $14.70 \pm 1.10$ & $12.09 \pm 1.08$ & $13.76 \pm 0.78$ \\
T1 & $14.19 \pm 0.71$ & $14.05 \pm 2.12$ & $13.16 \pm 0.70$ & $13.99 \pm 1.72$ \\
T2 & $14.62 \pm 0.63$ & $13.66 \pm 1.35$ & $13.11 \pm 1.74$ & $13.62 \pm 1.13$ \\
T3 & $14.70 \pm 2.06$ & $12.69 \pm 2.93$ & $12.37 \pm 2.45$ & $12.35 \pm 0.52$ \\
\hline
\end{tabular}

${ }^{1)}$ See the Table 1.

Values are mean \pm standard deviation.

Table 7. Changes in thiobarbituric acid reactive substances (TBARS) of pork patty during storage at $3 \pm 1^{\circ} \mathrm{C} \quad(\mathrm{mg} \mathrm{MA} / \mathrm{kg}$ )

\begin{tabular}{ccccc}
\hline \multirow{2}{*}{ Pork patty $^{1)}$} & \multicolumn{4}{c}{ Storage time (days) } \\
\cline { 2 - 5 } & 0 & 3 & 6 & 9 \\
T0 & $0.59 \pm 0.04^{\mathrm{dA}}$ & $2.99 \pm 0.02^{\mathrm{CA}}$ & $3.31 \pm 0.01^{\mathrm{bA}}$ & $4.57 \pm 0.01^{\mathrm{aA}}$ \\
T1 & $0.37 \pm 0.01^{\mathrm{dB}}$ & $1.22 \pm 0.02^{\mathrm{CB}}$ & $1.62 \pm 0.01^{\mathrm{bB}}$ & $1.85 \pm 0.01^{\mathrm{aB}}$ \\
T2 & $0.21 \pm 0.11^{\mathrm{CC}}$ & $0.32 \pm 0.02^{\mathrm{bC}}$ & $0.40 \pm 0.01^{\mathrm{aC}}$ & $0.43 \pm 0.03^{\mathrm{aC}}$ \\
T3 & $0.10 \pm 0.01^{\mathrm{dD}}$ & $0.30 \pm 0.00^{\mathrm{cD}}$ & $0.37 \pm 0.02^{\mathrm{bC}}$ & $0.41 \pm 0.01^{\mathrm{aC}}$ \\
\hline
\end{tabular}

${ }^{1)}$ See the Table 1.

Values are mean \pm standard deviation.

${ }^{\mathrm{a}-\mathrm{c}}$ Means with different superscripts in the same row significantly differ at $p<0.05$.

${ }^{\mathrm{A}-\mathrm{C}}$ Means with different superscripts in the same column significantly differ at $p<0.05$.

것은 돈육 패티 제조과정에 첨가한 소금이 냉장 중 근원섬유 단백질의 용해도를 증가시켜 유화력이 증가하였기 때문이며, 그 이후 보수력이 감소하는 것은 단백질의 분해가 진행되면서 수분의 유출이 용이해졌기 때문인 것으로 판단된다. 그러나 연근 및 연잎분말의 첨가는 돈육 패티의 보수력, 가열감량, 두께 증가율 및 직경 감소율에는 영향을 미치지 않았다.

기계적 조직감 측정에서 Choi 등[10]은 연잎분말을 첨가한 계육 패티가 저장기간이 경과하면서 경도 및 저작성은 높아지 고, 탄성은 낮아진다고 보고하여 본 연구의 결과와 일치하는 경향이었다. 따라서 연잎분말의 첨가는 저장기간이 경과한 돈 육 패티의 경도 및 저작성을 낮게 하고, 탄성을 향상시켜 기계 적 조직감을 향상시킬 수 있을 것으로 판단된다.

육제품의 $\mathrm{pH}$ 는 냉장기간이 경과하면서 상승하기도 하고 [19], 저하하기도 하는데[18], 이것은 미생물에 의한 젖산의 축 적[20] 또는 염기성 물질의 형성[37], 원료의 상태, 첨가물의 종류, 배합비율, 저장 조건 등이 영향을 미친다. 본 연구에서 냉장 중 $\mathrm{pH}$ 가 상승하는 것은 저장초기부터 존재한 미생물이 냉장과정에서 작용하여 염기성 물질을 생성하여 나타난 결과 로 판단된다. 그리고 저장초기부터 6일까지 연잎분말을 첨가 한 돈육 패티의 $\mathrm{pH}$ 가 낮은 것은 연잎 분말에 함유된 malic acid, succinic acid, acetic acid, glutaric acid 등의 유기산[38] 이 영향을 미친 것으로 여겨진다. 따라서 연잎분말의 첨가는 저장초기의 $\mathrm{pH}$ 에는 영향을 미치지만 저장기간이 길어지면 영 향이 없는 것으로 나타났다.

VBN 함량은 단백질이 많이 함유된 육제품의 신선도를 예 측하는 수단으로 이용되고 있으며, $\mathrm{VBN}$ 의 생성은 단백질이
분해되어 albumose, 펩톤, 펩티드, 아미노산 등을 생성하고 [11], 이것이 세균의 환원작용에서 기인하는 것이기 때문에 $\mathrm{VBN}$ 함량은 세균의 증식과도 관계가 깊다. 본 연구에서 시료 들 사이에 VBN 함량의 차이가 없는 것은 저장초기 제품의 오염도가 같았고, 첨가된 연근 및 연잎분말의 양이 적어서 나 타난 결과로 여겨진다.

TBARS는 지방의 자동산화 과정에서 생성되는 malonaldehyde의 양을 측정함으로서 육제품에서 지방의 산화 지표로 이용된다[32]. 연근이나 연잎분말을 첨가한 돈육 패티의 TBARS가 대조군보다 낮은 것은 이들에게 함유되어 있는 hyperin, isoquercetin, astragalin, kaempferol, myricetin, catechin 등의 폴리페놀화합물의 항산화 작용 [2,29]에 기인한다. 따라서 돈육 패티를 제조할 때에 연근이나 연잎분말의 첨가는 지방의 산화를 억제할 수 있다.

연근 및 연잎분말의 첨가가 냉장 중 돈육 패티에 미치는 영향의 결과에서 연잎분말의 첨가는 기계적으로 측정한 적색 도를 낮게 하지만 최근 건강과 관련하여 색깔이 있는 여러 가지 분말을 첨가하는 것이 일상화 되어 즉, 쑥 분말, 녹차 분말 등을 첨가한 떡이나 빵과 같은 제품에서 시각적으로 적 응이 되어 보기 좋은 녹색을 띄고 있었다. 그리고 물성에 영향 을 미치는 보수력, 가열감량, 두께 증가, 직경 감소 등은 연근 및 연잎분말의 첨가가 영향을 미치지 않았으며, 경도, 탄성 및 저작성은 연근과 연잎분말을 함께 사용하거나 연잎분말을 단독으로 사용하는 경우 개선되었다. 지방의 산화를 예측하는 TBARS도 연근과 연잎분말을 함께 사용하거나 연잎분말을 단 독으로 사용하는 경우 증가속도가 현저하게 줄었다. 따라서 
연근과 연잎분말을 병행해서 사용하거나 연잎분말을 단독으 로 돈육 패티에 사용할 경우 물성을 저해하지 않는 범위 내에 서 지질의 산화를 억제할 수 있으므로 이들을 이용하여 기능 성 육제품의 생산이 가능할 것으로 판단되며, 여기에 대한 연 구가 더욱 구체적으로 이루어져야 하겠다.

\section{References}

1. Arunyanart, S. and M. Chaitrayagun. 2005. Induction of somatic embryogenesis in lotus (Nelumbo nucifera Geartn.). Scientia Horticulturae 105, 411-420.

2. Awatif, E., B. Catharine, I. G. Alexander, P. M. Simon, G. S. Graham, and D. W. Roger. 2003. Two very unusual macrocyclic flavonoids from the water lily Nymphaea lotus. Phytochemistry 63, 727-731.

3. Bampids, V. A. and P. H. Robinson. 2006. Citrus by-products as ruminant feeds: A review. Anim. Feed Sci. Technol. 128, 175-217.

4. Bañón, S., P. Díaz, M. Rodríguez, D. G. María, and P. Alejandra. 2007. Ascorbate, green tea and grape seed extract increase the shelf life of low sulphite beef patties. Meat Sci. 77, 626-633.

5. Brannan, R. G. 2009. Effect of grape seed extract on descriptive sensory analysis of ground chicken during refrigerated storage. Meat Sci. 81, 589-595.

6. Buege, A. J. and S. D. Aust. 1978. Microsomal Lipid Peroxidation, Methods in Enzymology, In Gleischer S. and L. Parker. (eds.), pp. 302-310, Academic Press Inc., New York.

7. Chen, C. M. and G. R. Trout. 1991. Sensory, instrumental texture profile and cooking properties of restructured beef steaks made with various binders. J. Food Sci. 56, 1457-1460.

8. Chiang, P. Y. and Y. Y. Luo. 2007. Effects of pressurized cooking on the relationship between the chemical compositions and texture changes of lotus root (Nelumbo nucifera Geartn.). Food Chem 105, 480-484.

9. Choi, J. H., E. R. Jang, E. S. Lee, J. H. Choi, Y. S. Choi, D. J. Han, H. Y. Kim, M. A. Lee, S. Y. Shim, and C. J. Kim. 2011. Oxidative and color stability of cooked ground pork containing lotus leaf (Nelumbo nucifera) and barly leaf (Hordeum vulgare) powder during refrigerated storage. Meat Sci. $87,12-18$.

10. Choi, Y. S., J. H. Choi, H. Y. Kim, H. W. Kim, M. A. Lee, H. J. Chung, S. K. Lee, and C. J. Kim. 2011. Effect of lotus (Nelumbo nucifera) leaf powder on the quality characteristics of chicken patties in refrigerated storage. Korean J. Food Sci. Ani. Resour. 31, 9-18.

11. Coresopo, F. L., R. Millan, and A. S. Moreno. 1978. Chemical changes during ripening of Spanish dry. III. Changes in water soluble N-compounds. A Archivos de Zootechia 27, 105-108.

12. Eim, V. S., S. Simal, C. Rosselló, and A. Femenia. 2008. Effects of addition of carrot dietary fibre on the ripening process of a dry fermented sausage (sobrassada.). Meat Sci. 80, 173-182.
13. Fasseas, M. K., K. C. Mountzouris, P. A. Tarantilis, M. Polissiou, and G. Zervas. 2007. Antioxidant activity in meat treated with oregano and sage essential oils. Food Chem 106, 1188-1194.

14. Huang, B., J. S. He, X. Q. Ban, H. Zeng, X. C. Yao, and Y. W. Wang. 2011. Antioxidant activity of bovine and porcine meat treated with extracts from edible lotus (Nelumbo nucifera) rhizome knot and leaf. Meat Sci. 87, 46-53.

15. Hoffman, K., R. Hamm, and E. Blüchel. 1982. Neues über die bestimmung der wasserbindung des fleisches mit hilfe der filterpapierpress methode. Fleischwirtschaft 62, 87-93.

16. Huff-Lonergan, E. and S. M. Lonergan. 2005. Mechanism of water-holding capacity of meat: the role of postmortem biochemical and structural changes. Meat Sci. 71, 194-204.

17. Jung, I. C., S. J. Kang, J. K. Kim, J. S. Hyun, M. S. Kim, and Y. H. Moon. 2003. Effects of addition of perilla leaf powder and carcass grade on the quality and palatability of pork sausage. J. Korean Soc. Food Sci. Nutr. 32, 350-355.

18. Jung, I. C., K. S. Lee, and Y. H. Moon. 2009. Changes in the quality of ground beef with additions of medicinal plants (Cinnamon, Licorice and bokbunja) during cold storage. J. East Asian Soc. Dietary Life 19, 224-230.

19. Kang, S. N., S. K. Jin, M. R. Yang, and I. S. Kim. 2010. Changes in quality characteristics of fresh pork patties added with tomato powder during storage. Korean J. Food Sci. Ani. Resour. 30, 216-222.

20. Keeton, J. T. 1993. Effect of fat and $\mathrm{NaCl} /$ phosphate levels on the chemical and sensory properties of pork patties. $J$. Food Sci. 48, 129-232.

21. Korean Food \& Drug Administration. 2009. Food Code pp. 212-251, Munyoungsa, Seoul.

22. Lindahl, G., A. C. Enfält, G. von Seth, Ă. Joseli, I. Hedebro-Velander, H. J. Andersen, M. Braunschweig, A. Andersson, and K. Lundström. 2004. A second mutant allele (V1991) at the PRKAG3 (RN) locus-II. Effect on colour characteristics of pork loin. Meat Sci. 66, 621-627.

23. Ma, W. Y., Y. B. Lu, R. L. Hu, J. H. Chen, Z. Z. Zhang, and Y. J. Pan. 2010. Application of ionic liquids based microwave-assisted extraction of three alkaloids $\mathrm{N}$-nornuciferine, O-nornuciferine, and nuciferine from lotus leaf. Talanta 80, 1292-1297.

24. MaCarthy, T. L., J. P. Kerry, J. F. Kerry, P. B. Lynch, and D. J. Buckley. 2001. Assessment of the antioxidation potential of natural food and plant extracts in fresh and previously frozen pork patties. Meat Sci. 57, 177-184.

25. Martínez, L., I. Cilla, J. A. Beltrán, and P. Roncalés. 2007. Effect of illumination on the display life of fresh pork sausage packaged in modified atmosphere. Influence of the addition of rosemary, ascorbic acid and black pepper. Meat Sci. 75, 443-450.

26. Minussi, R. C., M. Rossi, L. Bologna, L. Cordi, D. Rptilio, G. M. Pastore, and N. Duran. 2003. Phenolic compounds and total antioxidant potential of commercial wine. Food Chem 82, 409-416;

27. Montesinos-Herroro, C., M. A. del Río, C. Pastor, O. Brunetti, and L. Palou. 2009. Evaluation of brief potassium sorbate 
dips to control postharvest Penicillium decay on major citrus species and cultivars. Postharvest Biol. Technol. 52, 117-125.

28. Namiki, M. 1990. Antioxidants/antimutagens in food. Cri. Rev. Food Sci. Nutr. 29, 273-300.

29. Ohkoshi, E., H. Miyazaki, K. Shindo, H. Watanabe, A. Yoshida, and H. Yajima. 2007. Constituents from the leaves of Nelumbo nucifera stimulate lipolysis in the white adipose tissue of mice. Plant Medica 73, 1255-1259.

30. Park, I. B., J. W. Park, J. M. Kim, S. T. Jung, and S. G. Kang. 2005. Quality of soybean paste (Doenjang) prepared with lotus root powder. J. Korean Soc. Food Sci. Nutr. 34, 519-523.

31. Park, K. D., J. H. Choi, and H. S. Sung. 1982. Color evaluation of commercial dehydrated tea-products by Hunter-Lab tristimulus colorimeter. Korean J. Nutr. Food 11, 25-30.

32. Raharjo, M. C. and M. S. Brewer. 1993. Effect of natural antioxidants on oxidative stability of cooked, refrigerated beef and pork. J. Food Sci. 72, 282-288.

33. Sánchez-Escalante, A., G. Torrescano, D. Djenane, J. A. Beltrán, and P. Roncalés. 2003. Stabilization of colour and odour of beef patties by using lycopene-rich tomato and peppers as a source of antioxidants. J. Sci. Food Agric. 83, 187-194.
34. Sebranek, J. G., V. J. H. Sewalt, K. L. Robbins, and T. A. Houser. 2005. Comparison of a natural rosemary extract and BHA/BHT for relative antioxidant effectiveness in pork sausage. Meat Sci. 69, 289-296.

35. Singh, N. and P. S. Rajini. 2008. Antioxidant-mediated protective effect of potato peel extract in erythrocytes against oxidative damage. Chemico-Biological Interactions 173, 97-104.

36. Verma, M. M., D. A. Ledward, and R. A. Lawrie. 1984. Lipid oxidation and metmyoglobin formation in sausage containing chickpea flour. Meat Sci. 11, 171-189.

37. Verma, S. P. and J. Sahoo. 2000. Improvement in the quality of ground chevon during refrigerated storage by tocopherol acetate preblending. Meat Sci. 61, 355-365.

38. Yang, H. C., N. C. Heo, K. C. Choi, and Y. J. Ahn. 2007. Nutritional composition of white-flowered and pink-flowered lotus in different parts. Korean J. Food Sci. Technol. 39, 14-19.

39. Youn, D. H., Y. H. Moon, and I. C. Jung. 2007. Changes in quality of pork patty containing red wine cold storage. Korean J. Life Sci. 17, 91-96.

40. Yuka, O., H. Eri, F. Yukitaka, I. Shoji, and O. Yasushi. 2006. Anti-obesity effect of Nelum bo nucifera leaves extract in mice and rats. J. Ethnopharmacology 106, 238-244.

\section{초록 : 냉장 중 연근 및 연잎분말을 첨가한 돈육 패티의 품질변화}

박경숙 ${ }^{*}$ 박현숙 ${ }^{1} \cdot$ 최영준 $^{1} \cdot$ 문윤희 $^{2} \cdot$ 이경수 ${ }^{3} \cdot$ 김민주 $^{4} \cdot$ 정인철 $^{1}{ }^{*}$

( ${ }^{1}$ 대구공업 대학 호텔외식조리계열, ${ }^{2}$ 경성대학교 식품생명공학과, ${ }^{3}$ 영남이공대학 식음료조리계열, ${ }^{4}$ 한진상사)

본 연구는 연근 및 연잎분말의 첨가가 돈육 패티의 저장 중 품질에 미치는 영향을 규명하고자 하였다. 돈육 패티는 돈육 $88 \%$, 대두유 $5 \%$, 냉수 $5 \%$, 소금 $2 \%$ 를 배합하여 제조한 대조군(T0), 여기에 연잎분말 $0.5 \%$ 첨가한 것(T1), 연근분말 $0.25 \%$ 및 연잎분말 $0.25 \%$ 첨가한 것(T2), 그리고 연잎분말 $0.5 \%$ 첨가한 것(T3) 등 네 종류의 돈육 패티를 제조하였다. 이들은 저장 중 색깔, 보수력, 가열감량, 두께 증가율, 직경 감소율, 기계적 조직감, $\mathrm{pH}$, VBN 함량 및 TBARS값을 측정하였다. 저장 중 $\mathrm{a}^{*}$ 값은 감소하는 경향이었다 $(p<0.05) . \mathrm{T} 3$ 의 $\mathrm{L}^{*}$ 및 $\mathrm{a}^{*}$ 값이 가장 낮았 으며, $\mathrm{b}^{*}$ 값은 $\mathrm{T} 2$ 및 T3가 T0 및 T1보다 높았다( $\left.p<0.05\right)$. 보수력은 저장 중 유의하게 낮았으며 $(\beta<0.05)$, 시료들 사이 에 보수력, 가열감량, 두께 증가율 및 직경 감소율의 차이는 없었다. 저장기간이 경과하면서 경도 및 저작성은 증가하였으며, 탄성은 감소하였다 $(p<0.05) . \mathrm{pH}$ 는 저장 중 높아지는 경향이었다 $(p<0.05) . \mathrm{VBN}$ 함량은 저장 중 변 화가 없었으며, 시료들 사이에도 유의한 차이가 없었다. TBARS값은 저장 중 유의하게 증가하여 저장 9 일째 $\mathrm{T} 0$, $\mathrm{T} 1, \mathrm{~T} 2$ 및 T3가 각각 $4.57,1.85,0.43$ 및 $0.41 \mathrm{mg} \mathrm{MA} / \mathrm{kg}$ 을 나타내었다( $p<0.05)$. 이상의 결과, 연근과 연잎분말을 병행 하거나 연잎분말을 단독으로 사용할 경우 기능성 육제품의 제조가 가능할 것으로 여겨진다. 